\title{
Decomposition and stabilization of organic matter in an old-growth tropical riparian forest: effects of soil properties and vegetation structure
}

Pedro Henrique de Godoy Fernandes ${ }^{1}$, Andréa Lúcia Teixeira de Souza ${ }^{2}$, Marcel Okamoto Tanaka ${ }^{2 *}$ (D) and Renata Sebastiani ${ }^{3}$

\begin{abstract}
Background: Nutrient cycling in tropical forests has a large importance for primary productivity, and decomposition of litterfall is a major process influencing nutrient balance in forest soils. Although large-scale factors strongly influence decomposition patterns, small-scale factors can have major influences, especially in old-growth forests that have high structural complexity and strong plant-soil correlations. Here we evaluated the effects of forest structure and soil properties on decomposition rates and stabilization of soil organic matter using the Tea Bag Index (TBI) in an old-growth riparian forest in southeastern Brazil. These data sets were described separately using Principal Components Analysis (PCA). The main axes for each analysis, together with soil physical properties (clay content and soil moisture), were used to construct structural equations models that evaluated the different parameters of the TBI, decomposition rates and stabilization factor. The best model was selected using Akaike's criterion.
\end{abstract}

Results: Forest structure and soil physical and chemical properties presented large variation among plots within the studied forest. Clay content was strongly correlated with soil moisture and the first PCA axis of soil chemical properties, and model selection indicated that clay content was a better predictor than this axis. Decomposition rates presented a large variation among tea bags $\left(0.009\right.$ and $\left.0.098 \mathrm{~g} \cdot \mathrm{g}^{-1} \cdot \mathrm{d}^{-1}\right)$ and were positively related with forest structure, as characterized by higher basal area, tree density and larger trees. The stabilization factor varied between $0.211-0.426$ and was related to forest stratification and soil clay content.

Conclusions: The old-growth forest studied presented high heterogeneity in both forest structure and soil properties at small spatial scales, that influenced decomposition processes and probably contributed to small-scale variation in nutrient cycling. Decomposition rates were only influenced by forest structure, whereas the stabilization factor was influenced by both forest structure and soil properties. Heterogeneity in ecological processes can contribute to the resilience of old-growth forests, highlighting the importance of restoration strategies that consider the spatial variation of ecosystem processes.

Keywords: Tea bag index, Forest structure, Carbon fixation, Nutrient cycling

\footnotetext{
*Correspondence: marcel@ufscar.br

${ }^{2}$ Department of Environmental Sciences (DCAm), Federal University of São

Carlos, São Carlos, SP, Brazil

Full list of author information is available at the end of the article
}

\section{Springer Open}

(c) The Author(s). 2021 Open Access This article is licensed under a Creative Commons Attribution 4.0 International License, which permits use, sharing, adaptation, distribution and reproduction in any medium or format, as long as you give appropriate credit to the original author(s) and the source, provide a link to the Creative Commons licence, and indicate if changes were made. The images or other third party material in this article are included in the article's Creative Commons licence, unless indicated otherwise in a credit line to the material. If material is not included in the article's Creative Commons licence and your intended use is not permitted by statutory regulation or exceeds the permitted use, you will need to obtain permission directly from the copyright holder. To view a copy of this licence, visit http://creativecommons.org/licenses/by/4.0/. 


\section{Background}

Tropical forests generally occur on nutrient poor soils, and the maintenance of primary productivity strongly depends on nutrient cycling within these ecosystems (Sayer and Banin 2016). Litterfall represents the main source of nutrients to the soil. Once leaves are deposited there, they go through a breakdown process called decomposition. This process includes the physical fragmentation of complex molecules in the litter into simpler organic and inorganic compounds that can be mineralized and absorbed by the plant community (Osman 2013; Berg and McClaugherty 2014; Pausas and Bond 2020). Litter decomposition progresses exponentially, since the organic matter is composed by fractions that are chemically labile and recalcitrant. Molecules to be decomposed spend more or less time in the soil, which will influence carbon fixation and soil structure (Berg 2018). Therefore, decomposition of organic matter can strongly influence local and global biogeochemical cycles (Benbow et al. 2019; Sayer et al. 2020).

Further, not all litter is necessarily mineralized, some of it can also stabilize or decompose at very slow rates, affecting soil organic matter (SOM) stocks (Berg 2018). The fraction that is stabilized and the decomposition rate depend on litter quality, temperature and humidity, and soil nutrient availability, since they influence decomposer activity (Berg 2014; Bradford et al. 2016; Lajtha et al. 2018; Wiesmeier et al. 2019).

These factors can be strongly influenced by vegetation structure and soil properties, which in turn, can vary immensely at local scales (Bradford et al. 2016, 2017). Soil properties can vary among ecosystems even at small scales, and can be related with the structure and composition of plant communities (Spielvogel et al. 2016; Metzger et al. 2017). Forest structure can also vary with contrasting spatial scales due to differences in species composition, internal dynamics, and physical factors (Wekesa et al. 2019; Muñoz Mazón et al. 2020). The structural heterogeneity found within forests can influence local microclimate conditions, hydrological movements, litterfall patterns, and also the soil physical and chemical properties (Krishna and Mohan 2017; Bélanger et al. 2019). For example, forest sites with more developed canopies and higher tree density produce more leaf litter (Nunes and Pinto 2007) increasing resource availability to the decomposer community. Variations in litterfall biomass could promote heterogeneity in decomposer activity (Lajtha et al. 2018; Silva-Sánchez et al. 2019). Further, higher forest stratification can provide higher radiation input, increasing temperatures and reducing soil moisture (Yeong et al. 2016), and factors that can influence decomposition rates (Petraglia et al. 2019). Therefore, litter decomposition can vary with different spatial scales in unmanaged old-growth forests due to higher heterogeneity, differences in litter spatial distribution, and variation in surface and subsurface hydrological pathways.

Riparian forests may present large spatial variation, related to the distance from watercourses, topography, geomorphology, and composition (Rot et al. 2000; Naiman et al. 2005). In response to this heterogeneity, there may be large spatial variation in soil properties and composition of plant communities, which then contribute with spatial variation in processes such as nutrient and carbon cycling (Parron et al. 2011; Woodward et al. 2015)

The evaluation of environmental factors that influence the decomposition and stabilization of the organic matter can be carried out by using leaf litter with different qualities, since several factors can influence the decomposition of the labile and recalcitrant fractions of the organic matter (Manzoni et al. 2012). With these considerations, Keuskamp et al. (2013) proposed the Tea Bag Index method (TBI), which used standard leaf litter with higher (green tea) and lower (rooibos tea) quality to obtain estimates of decomposition and stabilization of the organic matter, using an asymptotic model of mass loss (Wider and Lang 1982). The usage of standard material enables the evaluation of environmental factors, independently of the effect of leaf litter quality to decomposition rates (Keuskamp et al. 2013). Also, the material (green and rooibos tea) used in the TBI assessment is representative of the leaf litter found in natural ecosystems (Duddigan et al. 2020).

In this study, we evaluated the decomposition rates and stabilization of the organic matter in a tropical oldgrowth riparian forest in southeastern Brazil. We evaluated whether forest structure and soil properties could influence these processes using standard TBI methods (Keuskamp et al. 2013). In this way, we aimed to identify which factors influenced decomposition at small scales in old-growth forests, contributing to the identification of indicators for the monitoring of restored forests.

\section{Methods \\ Study area}

This study was carried out in a highly preserved remnant of riparian forest that belongs to the Air Force Base of Pirassununga (FAYS) in central São Paulo state $\left(21^{\circ} 59^{\prime}\right.$ 39.98" S, 47²0'12.73" W), Southeastern Brazil. FAYS includes a total forest area of 2608 ha, which about $45 \%$ is composed of semideciduous seasonal forest and transition areas with riparian forest. The studied forest is adjacent to the Mogi-Guaçu River, in the upper Paraná River watershed, and is part of a 140-ha forest fragment at $620 \mathrm{~m}$ above sea level. The region is in the residual plateaus of Franca/Batatais and is composed by intrusive 
Serra Geral, with deep distroferric red latosols, and a wavy relief (Rossi 2017).

Climate is Cwa following Köppen's classification, with wet summers and dry winters (Souza et al. 2007). Between 1976 and 2008, the mean minimum and maximum temperatures recorded at FAYS were $10.6^{\circ} \mathrm{C}$ and $32.8^{\circ} \mathrm{C}$, respectively, and mean annual rainfall was 1290 $\mathrm{mm}$ (Ferrari et al. 2012). The experiment was carried out in the early dry season (24 April to 24 June 2019). Mean temperatures and monthly rainfall recorded in May were $23.7^{\circ} \mathrm{C}$ and $39.4 \mathrm{~mm}$, and in June $21.2^{\circ} \mathrm{C}$ and $16.2 \mathrm{~mm}$, respectively, in the meteorological station of University of São Paulo, campus Pirassununga, located about $15 \mathrm{~km}$ from FAYS.

\section{Sampling design}

We evaluated the effects of spatial variation in soil properties and forest structure on the decomposition and stabilization of the organic matter by establishing ten 10 $\mathrm{m} \times 10 \mathrm{~m}$ plots in a riparian forest, five plots distant $5 \mathrm{~m}$ from the Mogi-Guaçu River and five plots at a 30-m distance from the river. We selected these areas to maximize the variation in soil physical properties, since areas near the river generally have more sand and less clay than those in the forest interior (Woodward et al. 2015; Rodrigues et al. 2018; Saint-Laurent and Arsenault-Boucher 2020). Also, we expected that forest structure would differ between these areas due to higher incidence of light near the river. Within each distance, each plot was $30 \mathrm{~m}$ distant from each other.

Soil sampling and the assessment of forest structure were carried out just before the experiment began. Soil samples from each plot were obtained by randomly collecting three $0-20 \mathrm{~cm}$ depth subsamples with an auger, which were then mixed to form a single sample. In the laboratory, a subsample $(50 \mathrm{~g})$ was separated from each compound sample to assess soil moisture. Initially, the subsample's wet mass was determined and then it was reweighted after being dried at $65^{\circ} \mathrm{C}$ in an oven. This step ensured that the dry mass had been stabilized before the second weighing. Soil moisture was then obtained as $h=$ (wet mass - dry mass)/dry mass $\times 100$. Clay content was determined using the pipette method (Embrapa 1997). Soil chemical analyses were carried out following Embrapa (1997) and van Raij et al. (2001): available phosphorus $(\mathrm{P})$, potassium $(\mathrm{K})$, calcium $(\mathrm{Ca})$, and magnesium $(\mathrm{Mg})$ were determined with the anion exchange method; soil organic matter was determined with the Walkley-Black method, $\mathrm{pH}$ was determined with $\mathrm{CaCl}_{2}$ solution at $0.01 \mathrm{~mol} \cdot \mathrm{L}^{-1}$; nitrogen $(\mathrm{N})$ was determined with the Kjeldahl method, and potential acidity $(\mathrm{H}+\mathrm{Al})$ was determined with a buffered solution of calcium acetate at $\mathrm{pH}=7$. Cation exchange capacity (CEC) was obtained from the sum $\mathrm{K}+\mathrm{Ca}+\mathrm{Mg}+(\mathrm{H}+$
$\mathrm{Al}$ ), and soil base saturation (BS) was calculated by dividing the sum of bases $(\mathrm{K}+\mathrm{Ca}+\mathrm{Mg})$ by $\mathrm{CEC}$.

Forest structure characterization was adapted from Souza et al. (2013) by using a measuring tape to sample every tree in each plot that had a circumference at breast height $(\mathrm{CBH})>10 \mathrm{~cm}$. For each plot we then determined mean diameter at breast height $(\mathrm{DBH})$, tree stratification (calculated as the coefficient of variation of DBH), tree density (individuals $\left.\cdot h \mathrm{a}^{-1}\right)$, and plot basal area $\left(\mathrm{m}^{2} \cdot \mathrm{ha}^{-1}\right)$.

We estimated the decomposition rates and stabilization factor of the organic matter using the TBI method (Keuskamp et al. 2013). In this method, a pair of tea bags, manufactured by Lipton ${ }^{\circ}$, is buried at $8-\mathrm{cm}$ depth. Each tea bag has a different $\mathrm{C}: \mathrm{N}$ content and therefore distinct litter quality: green tea (sencha tea, C: $\mathrm{N}$ ratio $=12.2$ ) and red tea (rooibos tea, $\mathrm{C}: \mathrm{N}=42.9$ ) (Keuskamp et al. 2013). The tea bags are made of polypropylene and have a tetrahedral shape with $5-\mathrm{cm}$ sides, containing about $2.0 \mathrm{~g}$ of tea. A pair containing one tea bag of each type is buried $15 \mathrm{~cm}$ from another pair. Five pairs were randomly buried in each plot at a minimum distance of $2 \mathrm{~m}$ from the plot sides, resulting in a total of 100 tea bags buried in 24 April 2019. One day before the experiment was set up, 55 bags from each tea type were weighed in the lab with a balance (precision $=0.0001 \mathrm{~g}$ ). The five extra bags from each tea type were carried to the field but were not buried and were used as manipulation controls. After returning from the field, they were weighed, dried in an oven at $60^{\circ} \mathrm{C}$ for $72 \mathrm{~h}$, and weighed again. We combined both measures to obtain a single correction factor to account for mass losses during transportation and humidity losses: 0.9433 for the green tea, and 0.9318 for the red tea. All initial mass values from the 100 tea bags were multiplied by the corresponding correction factor to obtain initial dry mass values for each bag.

After 2 months (24 June 2019), the tea bags were recovered and taken to the lab, where they were dried at $60^{\circ} \mathrm{C}$ in an oven for $72 \mathrm{~h}$. Each bag was then carefully brushed to remove soil particles and plant roots and then weighed. The final tea bag dry mass was obtained by subtracting $0.2424 \mathrm{~g}$ for the red tea and $0.2449 \mathrm{~g}$ for the green tea, which related to the weight of the bag itself, the threads, and the label. We left the tea bags for only 2 months instead of 3 months as suggested by Keuskamp et al. (2013) because in another experiment carried out in 2018 in the same region, and we lost many tea bags due to excessive decomposition (Soares et al. 2020). In these cases, Keuskamp et al. (2013) recommended a reduced incubation time because decomposition rates could be underestimated. The method assumes that the red tea is in the first phase of the decomposition, so that if it decomposes excessively, when the second phase of decomposition is considered, it is 
not possible to calculate $k$ (http://www.teatime4science. org/faq/). Even though the tea bags stayed only for 60 days, we still lost seven pairs of tea bags due to the high decomposition of the red tea.

The TBI model estimates the stabilization factor $(S)$ based upon the green tea decomposition, and the decomposition rate $(k)$ considering the red tea decomposition as fitted by the asymptotic model (Keuskamp et al. 2013):

$$
W_{\mathrm{r}}(t)=a_{\mathrm{r}} \mathrm{e}^{-k t}+\left(1-a_{\mathrm{r}}\right)
$$

where $W_{\mathrm{r}}(t)$ is the remaining mass of red tea after $t$ days, $a_{\mathrm{r}}$ is the labile fraction of the red tea, and $\left(1-a_{\mathrm{r}}\right)$ is the recalcitrant fraction. The labile fraction is estimated by:

$$
a_{\mathrm{r}}=H_{\mathrm{r}}(1-S)
$$

where $H_{\mathrm{r}}=0.552 \mathrm{~g} \cdot \mathrm{g}^{-1}$ and is the chemically hydrolysable fraction of the red tea, and $S$ is the stabilization factor (Keuskamp et al. 2013), estimated by:

$$
S=1-\frac{a_{\mathrm{g}}}{H_{\mathrm{g}}}
$$

where $H_{\mathrm{g}}=0.842 \mathrm{~g} \cdot \mathrm{g}^{-1}$, and is the chemically hydrolysable fraction of the green tea, and:

$$
a_{\mathrm{g}}=1-\frac{W_{\mathrm{f}_{\mathrm{g}}}}{W_{0_{\mathrm{g}}}}
$$

where $W_{\mathrm{f}_{\mathrm{g}}}$ and $W_{0_{\mathrm{g}}}$ are the final and initial masses of the green tea, respectively.

\section{Data analysis}

We used a Principal Components Analysis (PCA) to reduce the dimensionality of soil chemical variables. Concentrations of $\mathrm{K}$ and $\mathrm{P}$ were $\mathrm{ln}$-transformed to obtain normal distributions, which were then verified using Shapiro-Wilk tests. Subsequently, all variables were standardized for zero means and unity variance. We also used PCA to evaluate forest structure variables: forest stratification (coefficient of variation of DBH) was transformed using the Box-Cox method to obtain a normal distribution. For both PCA analyses we used the Kaiser criterion and selected axes with eigenvalues $>1$ (Legendre and Legendre 2012). We calculated the correlation between the resulting soil PCA axes and soil physical properties (soil moisture and clay content) with the Pearson Correlation Coefficient. Both variables were strongly correlated with the PCA first axis of chemical variables (Soil 1), as well as between each other.

The physical and chemical soil variables and vegetation structure were then used in a Structural Equations Model (SEM) as exogenous variables to evaluate their direct effects on decomposition rates $(k)$ and stabilization factors $(S)$ (Grace 2006). Vegetation structure was evaluated considering the first two PCA axes (Veg1 and Veg 2, see Results). To evaluate the effects of soil, we constructed three SEM models, each considering different effects of the physical variables. We used only clay content to summarize the physical variables because it was strongly correlated with soil moisture. The models were I) Clay content, Soil 1, Soil 2 (chemical and physical variables); II) Clay content, Soil 2 (chemical and physical variables); III) Soil 1, Soil 2 (only chemical variables). Model II considered that clay content and Soil 1 were highly correlated, but since clay content directly influences soil chemical properties, clay content would be enough to predict litter decomposition. We used model selection methods by considering AICc criterion to select the best model.

Considering that soil and vegetation covary, we also included correlations between soil and vegetation variables. Model fit was evaluated considering differences between the observed and predicted covariance structure, following the Comparative Fit Index (CFI), and the Root Mean Square Error of Approximation (RMSEA) (Hooper et al. 2008). These analyses were carried out using the lavaan package (Rosseel 2012) in R ( $R$ Core Team 2018).

\section{Results}

Soil physical and chemical properties and forest structure presented a large variation among plots (Table 1).

The two PCA axes related to soil chemical attributes explained $85.4 \%$ of the variance. The first axis (Soil 1) explained $60.2 \%$ of the variation (eigenvalue $=5.42$ ) and was positively correlated with $\mathrm{CEC}, \mathrm{OM}, \mathrm{BS}, \mathrm{pH}, \mathrm{N}$ and P (Fig. 1). The second axis (Soil 2) explained 25.2\% of the variation (eigenvalue $=2.27$ ) and was positively correlated with $\mathrm{K}$ and $\mathrm{N}: \mathrm{P}$ ratio, and negatively correlated with the C:N ratio (Fig. 1). The ordination indicated that the studied area included plots that presented a large variation in soil chemical properties, forming a gradient (Table 1, Fig. 1).

Soil chemical properties as indicated by the first PCA axis (Soil 1) were strongly correlated with clay content and soil moisture, whereas Soil 2 was not correlated with either variable (Table 2). Also, clay content and soil moisture were strongly correlated with each other (Table 2).

The PCA on forest structure variables explained 82.7\% of the variation in the first two axes. The first axis (Veg 1) explained $51.9 \%$ of the variance (eigenvalue $=2.07$ ) and was positively correlated with mean DBH, tree density, and basal area (Fig. 2). The second axis (Veg 2) explained $30.8 \%$ of the variation (eigenvalue $=1.23$ ) and was positively correlated with forest stratification and negatively correlated with mean $\mathrm{DBH}$ and tree density (Fig. 2). Therefore, the PCA indicated a large spatial 
Table 1 Mean, standard deviation (SD) and range of measured variables describing soil chemical and physical variables, forest structure, and variables estimated by the Tea Bag Index

\begin{tabular}{|c|c|c|c|}
\hline Variables & Mean & SD & Range \\
\hline \multicolumn{4}{|l|}{ Soil chemical properties $(n=10)$} \\
\hline $\mathrm{pH}\left(\mathrm{CaCl}_{2}\right)$ & 5.71 & 0.543 & $5.00-6.70$ \\
\hline$N\left(\mathrm{mg} \cdot \mathrm{kg}^{-1}\right)$ & 3627 & 1413 & $1974-6538$ \\
\hline$P\left(m g \cdot d m^{-3}\right)$ & 18.9 & 8.12 & $11.0-34.0$ \\
\hline $\mathrm{K}\left(\mathrm{mmol}_{c^{\prime}} \cdot \mathrm{dm}^{-3}\right)$ & 3.84 & 0.714 & $3.2-5.1$ \\
\hline$N: P$ & 198.0 & 44.27 & $123.4-247.5$ \\
\hline$C: N$ & 9.47 & 1.184 & $7.06-11.72$ \\
\hline $\mathrm{OM}\left(\mathrm{g} \cdot \mathrm{dm}^{-3}\right)$ & 59.6 & 26.09 & $34.0-113.0$ \\
\hline $\mathrm{CEC}\left(\mathrm{mmol}_{\mathrm{c}} \cdot \mathrm{dm}^{3}\right)$ & 133.0 & 61.83 & $67.2-224.7$ \\
\hline BS (\%) & 82.1 & 11.45 & $64.0-95.1$ \\
\hline \multicolumn{4}{|l|}{ Soil physical properties $(n=10)$} \\
\hline Soil moisture (\%) & 18.5 & 8.49 & $5.6-30.9$ \\
\hline Clay content (\%) & 9.4 & 5.20 & $3.0-18.4$ \\
\hline \multicolumn{4}{|l|}{ Forest structure $(n=10)$} \\
\hline Basal area $\left(\mathrm{m}^{2} \cdot h \mathrm{~h}^{-1}\right)$ & 46.2 & 21.88 & $19.1-97.0$ \\
\hline Mean DBH $(\mathrm{cm})$ & 8.15 & 1.161 & $6.30-9.85$ \\
\hline Forest stratification - CV DBH & 1.006 & 0.197 & $0.846-1.442$ \\
\hline Tree density (ind $\cdot h a^{-1}$ ) & 4200 & 666.7 & $3200-5100$ \\
\hline \multicolumn{4}{|l|}{ Tea Bag Index $(n=43)$} \\
\hline Decomposition rate $\left(k, g \cdot g^{-1} \cdot\right.$ day $\left.^{-1}\right)$ & 0.028 & 0.017 & $0.009-0.098$ \\
\hline Stabilization factor $(S)$ & 0.350 & 0.051 & $0.211-0.426$ \\
\hline
\end{tabular}

Table 2 Pearson's correlation coefficients between soil physical properties and soil chemical variables summarized by PCA axes 1 (Soil 1) and 2 (Soil 2). ${ }^{* * *} P<0.001$

\begin{tabular}{llcl}
\hline Predictor variables & Clay content & Soil moisture & PCA Soil 1 \\
\hline Soil moisture & $0.973^{* * *}$ & & \\
PCA Soil 1 & $0.968^{* * *}$ & $0.939^{* * *}$ & \\
PCA Soil 2 & 0.164 & 0.174 & 0
\end{tabular}

variation in relation to tree size, density, and forest stratification (CV DBH).

The three structural equations models showed a good fit to the covariance matrix $\left(\chi^{2}=0.022 ; P>0.900\right)$, with adequate values of the other model evaluation indicators $(\mathrm{CFI}=1.000$; RMSEA $=0.000, P>0.630)$. Model II presented the lowest AICc (537.7) when compared to models I (575.3) and III (664.4), and thus best explained the covariance matrix. In model II, Veg 1 (which was positively correlated with basal area and tree sizes) was not correlated with soil properties, whereas Veg 2 (which was correlated with forest stratification) was negatively correlated with clay content, indicating that higher forest stratification was found in less fertile plots that had lower clay content (Fig. 3). There was also a significant but weak positive correlation between the decomposition rate and the stabilization factor $(r=0.354$, $P=0.028$ ), suggesting that where decomposition was slower, more organic matter was stabilized.

Decomposition rates estimated from each pair of tea bags varied between 0.009 and $0.098 \mathrm{~g} \cdot \mathrm{g}^{-1} \cdot \mathrm{d}^{-1}(\mathrm{CV}=$ 0.60 , Table 1). Decomposition rates were related with Veg 1, indicating higher rates in plots with higher basal

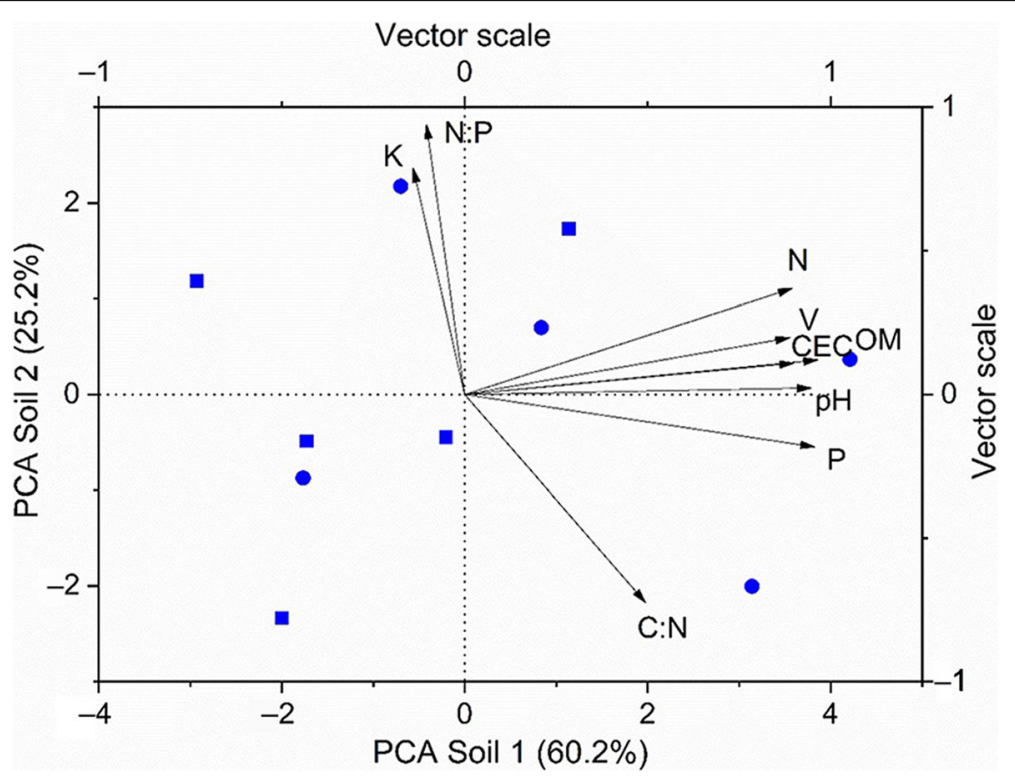

Fig. 1 Ordination of plots near the river (squares) and in the forest interior (circles) by Principal Components Analysis in relation to soil chemistry: cation exchange capacity (CEC), soil base saturation (V), soil organic matter (OM), nitrogen (N), phosphorus (P), potassium (K), N:P and C:N ratios 


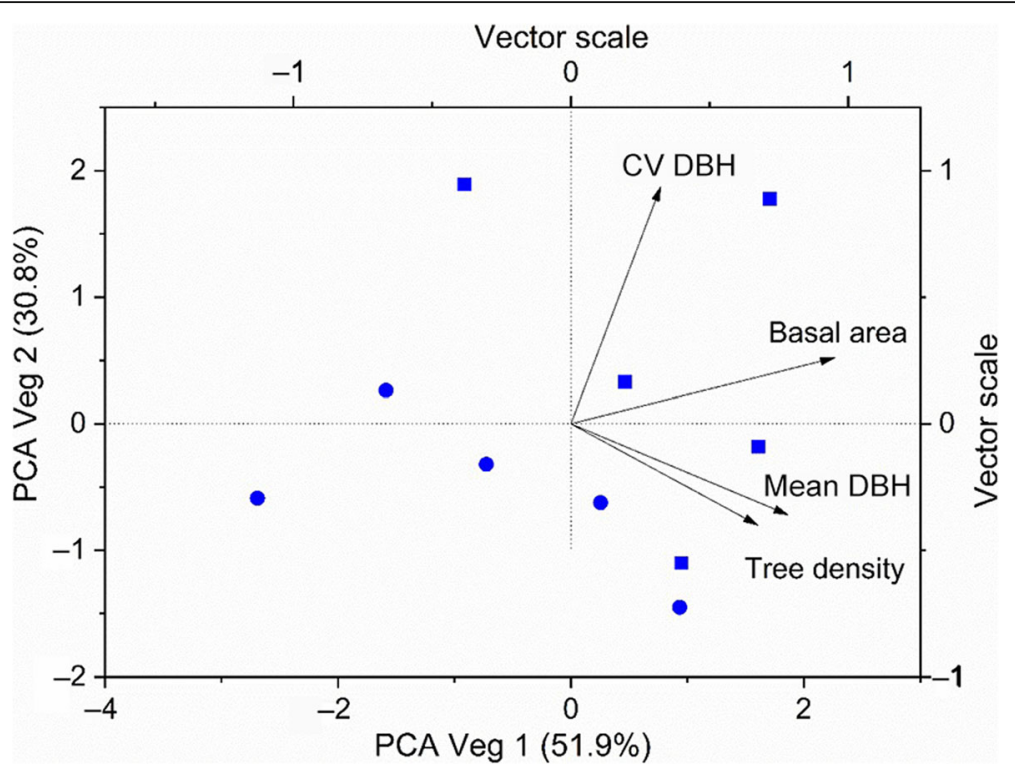

Fig. 2 Ordination of plots near the river (squares) and in the forest interior (circles) by Principal Components Analysis in relation to forest structure: basal area, tree density, mean DBH, and forest stratification (CV DBH)

areas and larger trees (Fig. 3), although this relationship explained relatively few $(19 \%)$ of the variation.

The stabilization factor $S$ varied between 0.211 and $0.426(\mathrm{CV}=0.15$, Table 1). The model explained $54 \%$ of the variation in the stabilization factor. The stabilization of the organic matter was positively influenced by clay content, with a negative effect of Veg 2, indicating lower stabilization of the organic matter in areas with higher forest stratification (Fig. 3).

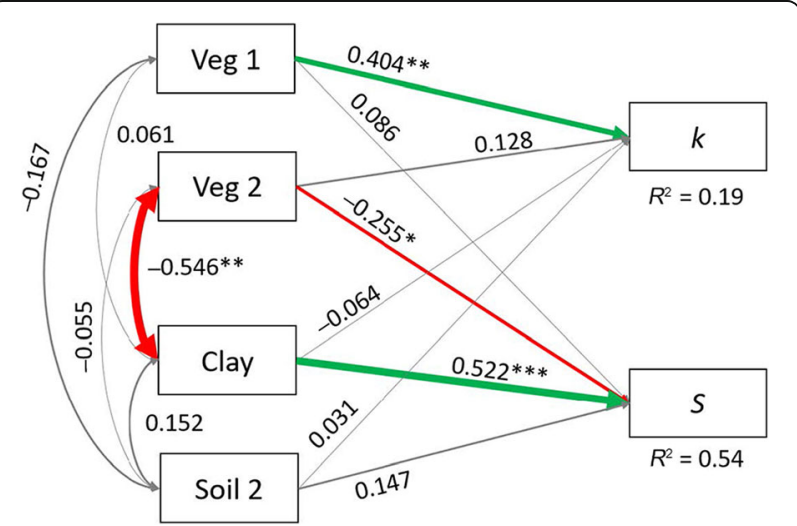

Fig. 3 Structural equation model depicting the effects of forest structure (Veg 1, Veg 2), clay content and soil chemical attributes (Soil 2) on decomposition rates ( $k$ ) and stabilization factor (S) as calculated by the Tea Bag Index. Arrow widths are proportional to the standardized coefficients, which are also indicated next to the line. ${ }^{*} P<0.05,{ }^{*} P<0.01,{ }^{* *} P<0.001$. Green arrows indicate positive effects, red arrows negative effects, and grey lines indicate non-significant effects $(P>0.10)$

\section{Discussion}

Litter decomposition can largely vary between oldgrowth and degraded forests due to differences in plant composition, microclimate, and soil attributes (Borders et al. 2006; Yeong et al. 2016). Therefore, comparative studies may not allow us to evaluate all the factors that may influence local decomposition, because the large structural and environmental variation between natural and degraded forests can obscure more subtle variations found in natural, preserved forests (Bradford et al. 2016). For example, Oliveira et al. (2019) studied a preserved tropical Atlantic Forest in Southern Brazil and found that both soil chemistry, canopy cover, and plant taxonomic and functional diversity influenced early leaf litter decomposition, with strong effects at spatial scales smaller than $5 \mathrm{~km}$.

Drivers of leaf litter decomposition at small spatial scales such as differences in soil attributes and forest structure and composition can influence the decomposition and stabilization of organic matter, sometimes with effects as large as those of drivers that operate at large spatial scales such as temperature and rainfall (Bradford et al. 2016, 2017). We found a large variation (an order of magnitude) in leaf litter decomposition rates, at a small scale, which was related only to the structure of the old-growth riparian forest. The stabilization of the organic matter was less variable and was strongly related to soil properties and forest structure.

The exogenous variables used as predictors of the decomposition process were not correlated with each other, except for the correlation between Veg 2 and clay 
content. However, since Veg 2 was highly correlated with forest stratification $(r=0.936)$, the correlation between forest structure and clay content should be evaluated with caution. Plots near the river presented higher forest stratification which may be due to higher light penetration when compared to plots in the forest interior. Since plots near the river presented lower clay content, the correlation between forest stratification and soil clay content can be spurious because these effects may be confounded with distance from the river. Although a correlation between forest structure and soil properties was found, the structural equations model allowed to separate the effects of each driver on the processes involved in the decomposition of the organic matter.

Decomposition rates were correlated with the first axis of forest structure (Veg 1), which was represented by areas with higher tree density, mean $\mathrm{DBH}$, and basal area. Forests with more developed canopies and higher tree densities present higher primary production and produce higher amounts of leaf litter (Teixeira et al. 2020). The additional leaf litter produced increases the amounts of available resources for decomposers, which can positively influence their activity (Nunes and Pinto 2007; Silva-Sánchez et al. 2019), rising decomposition rates (Lajtha et al. 2018). The tea bags initially used in the Tea Bag Index were made of $0.25-\mathrm{mm}$ woven nylon mesh, but now they are made of unwoven polypropylene; the bag material may limit the access of macro and most mesofauna (Setälä et al. 1996), so that most of the decomposition observed is due to microbial activity (Keuskamp et al. 2013).

Although significant, the correlation with Veg 1 explained few of the variation of decomposition rates (19\%), since our data indicated a high variation in the individual estimates of $k$. High individual variation in $k$ estimates was also found by Saint-Laurent and ArsenaultBoucher (2020) in their study on temperate riparian forests, but decomposition rates were not related with soil properties nor other environmental variables. The fitted SEM model showed that decomposition rates were directly related with forest structure while maintaining the other variables constant, suggesting that at this spatial scale the variation in vegetation is more important than other environmental factors such as differences in soil properties. The composition of old-growth forests may have more influence on soil communities, with the development of more specialized microbial communities depending on the leaf litter traits of different plant species, contributing to the heterogeneity in decomposition rates at this spatial scale (e.g., Austin et al. 2014). In addition, soil nutrient availability and soil fertility recorded in this old-growth forest were very high when compared with other riparian forests in the region (e.g., Soares et al. 2020), and it is possible that soil properties were not important for decomposition rates in our study because there were no limiting resources for decomposition; nevertheless, further studies are necessary to test this hypothesis.

Contrastingly, the SEM model explained $54 \%$ of the variation in the stabilization factor $S$, which was strongly influenced by soil properties. The selected model included clay content instead of Soil 1 as a predictor of $S$, even though these variables were highly correlated (Table 2). The strong correlation of clay content with Soil 1 indicates that areas that presented higher $S$ values were those with higher SOM, CEC, and soil base saturation, and variables that were strongly correlated with each other and with clay content. Also, several nutrients are correlated with clay content, including major cations, CEC, N, and P (Schoenholtz et al. 2000; Woodward et al. 2015; Aprile and Lorandi 2019). Since the tea was not in direct contact with clay surfaces, clays may have not directly influenced SOM formation, but may have had indirect effects by influencing the microbial community. The decomposition of the labile fraction enables the incorporation of this substrate in microbial biomass and in byproducts, which may constitute a large part of stabilized soil organic matter (Cotrufo et al. 2013). Considering that the stabilization factor is directly correlated to the transformation of the labile fraction into recalcitrant fraction (Keuskamp et al. 2013), these results suggest that this mechanism can strongly contribute to the stabilization of the organic matter and consequently carbon fixation in the soil.

The variation in the stabilization factor $S$ was also significantly influenced by Veg 2, suggesting that forest stratification can negatively influence $S$. Although Veg 2 was correlated with clay content, the SEM model suggests an independent, negative effect of forest stratification. This effect can be associated with the increased penetration of light into the forest, which can influence microclimatic factors such as temperatures at the soil level, increasing litter decomposition (Ottermanns et al. 2011; Mayer et al. 2017). Higher soil temperatures can reduce the stabilization factor $S$ independently of soil moisture (Petraglia et al. 2019). Our study showed that even at small spatial scales, differences in forest structure can influence the stabilization of organic matter.

The contribution of soil properties to the stabilization of organic matter can be lower in managed forests when compared to natural forests (Lukumbuzya et al. 1994; Berkelmann et al. 2018). In a study carried out in the same region, Soares et al. (2020) found a strong relationship between $S$ and soil base saturation in a riparian forest remnant, but did not find this relationship in a riparian forest under restoration. The factors that contribute to the variation on decomposition processes within old-growth forests can differ from those in 
degraded forests or those under restoration (Borders et al. 2006; Yeong et al. 2016; Zhou et al. 2018), pointing to the importance of understanding these processes at small spatial scales (Bradford et al. 2016). Therefore, natural forests may have mechanisms of organic matter stabilization that differ in relation to managed or degraded forests, mechanisms which need to be better understood.

\section{Conclusions}

Our study showed that decomposition drivers in forests can be associated to both vegetation structure and soil properties, although their relative influence depends on the decomposition parameter evaluated. Tree sizes and plot basal area positively influenced decomposition rates but did not influence the stabilization factor. On the other hand, forest stratification had negative effects, whereas clay content had strong positive effects on the stabilization factor. This heterogeneity at small spatial scales can contribute to the resilience of old-growth forests, strengthening ecosystem functions such as nutrient cycling and carbon fixation. Therefore, these findings highlight the importance of small-scale variation in monitoring restored areas to evaluate the recovery of ecosystem processes. Studies comparing the stabilization factor in soils within preserved and degraded forests could test these hypotheses and contribute to restoration techniques that aim to increase carbon fixation in the soil.

\section{Acknowledgements}

We thank the Air Force Base of Pirassununga (FAYS) for the permission to work at Guarnição da Aeronáutica de Pirassununga. We also thank Gustavo Galetti, Débora Bessi and José Victor Silva for help in the field and lab work, and Rebeca. L. Oliva for reviewing the manuscript.

\section{Authors' contributions}

All authors contributed to the study conception and design. Material preparation, data collection, and writing initial draft: PHGF. Data analysis, writing final version, review and editing: ALTS and MOT. All authors read and approved the final manuscript.

\section{Funding}

This study was supported by the Coordenação de Aperfeiçoamento de Pessoal de Nivel Superior - Brazil (CAPES) - Code Financing 001, and FAPESP (proc. 2018/21913-8).

\section{Availability of data and materials}

The datasets used and/or analyzed during the current study are available from the corresponding author on reasonable request.

\section{Ethics approval and consent to participate}

Not applicable.

\section{Consent for publication}

Not applicable.

\section{Competing interests}

The authors declare that they have no competing interest.

\section{Author details}

Graduate Program in Environmental Sciences, Federal University of São Carlos, São Carlos, SP, Brazil. ²Department of Environmental Sciences (DCAm), Federal University of São Carlos, São Carlos, SP, Brazil. ${ }^{3}$ Department of Nature, Mathematics, and Education Sciences, Federal University of São Carlos, São Carlos, SP, Brazil.

Received: 17 August 2020 Accepted: 2 February 2021

Published online: 09 February 2021

\section{References}

Aprile F, Lorandi R (2019) Cation exchange capacity (CEC) in tropical soils. Lambert Academic Publishing, Mauritius

Austin AT, Vivanco L, González-Arzac A, Pérez LI (2014) There's no place like home? An exploration of the mechanisms behind plant litter-decomposer affinity in terrestrial ecosystems. New Phytol 204:307-314. https://doi.org/1 $0.1111 / \mathrm{nph} .12959$

Bélanger N, Collin A, Ricard-Piché J, Kembel SW, Rivest D (2019) Microsite conditions influence leaf litter decomposition in sugar maple bioclimatic domain of Quebec. Biogeochemistry 145:107-126. https://doi.org/10.1007/s1 0533-019-00594-1

Benbow ME, Barton PS, Ulyshen MD, Beasley JC, DeVault TL, Strickland MS, Tomberlin JK, Jordan HR, Pechal JL (2019) Necrobiome framework for bridging decomposition ecology of autotrophically and heterotrophically derived organic matter. Ecol Monogr 89:e01331. https://doi.org/10.1002/ ecm.1331

Berg B (2014) Decomposition patterns for foliar litter - a theory for influencing factors. Soil Biol Biochem 78:222-232. https://doi.org/10.1016/j.soilbio.2014.08. 005

Berg B (2018) Decomposing litter; limit values; humus accumulation, locally and regionally. Appl Soil Ecol 123:494-508. https://doi.org/10.1016/j.apsoil.2017.06 026

Berg B, McClaugherty C (2014) Plant litter. Springer, Berlin

Berkelmann D, Schneider D, Engelhaupt M, Heinemann M, Christel S, Wijayanti M, Meryandini A, Daniel R (2018) How rainforest conversion to agricultural systems in Sumatra (Indonesia) affects active soil bacterial communities. Front Microbiol 9:2381. https://doi.org/10.3389/fmicb.2018.02381

Borders BD, Pushnik JC, Wood DM (2006) Comparison of leaf litter decomposition rates in restored and mature riparian forests on the Sacramento River, California. Restor Ecol 14:308-315. https://doi.org/10.1111/ j.1526-100X.2006.00133.x

Bradford MA, Berg B, Maynard DS, Wieder WR, Wood SA (2016) Understanding the dominant controls on litter decomposition. J Ecol 104:229-238. https:// doi.org/10.1111/1365-2745.12507

Bradford MA, Ciska GF, Bonis A, Bradford EM, Classen AT, Cornelissen JHC, Crowther TW, De Long JR, Freschet GT, Kardol P, Manrubia-Freixa M, Maynard DS, Newman GS, Logtestijn RSP, Viketoft M, Wardle DA, Wieder WR, Wood SA, van der Putten WH (2017) A test of the hierarchical model of litter decomposition. Nat Ecol Evol 1:1836-1845. https://doi.org/10.1038/s41559-01 7-0367-4

Cotrufo MF, Wallenstein MD, Boot CM, Denef K, Paul E (2013) The microbial efficiency-matrix stabilization (MEMS) framework integrates plant litter decomposition with soil organic matter stabilization: do labile plant inputs form stable soil organic matter? Glob Chang Biol 19:988-995. https://doi. org/10.1111/gcb.12113

Duddigan S, Shaw L, Alexander PD, Collins CD (2020) Chemical underpinning of the tea bag index: an examination of the decomposition of tea leaves. Appl Environ Soil Sci 2020:6085180. https://doi.org/10.1155/2020/6085180

Embrapa (1997) Manual de Métodos de Análise de Solo. Emprapa, Rio de Janeiro

Ferrari AL, Vecchia FADS, Colabone RDO (2012) Tendência e variabilidade anuais da temperatura e da pluviosidade em Pirassununga-SP. Rev Bras Climatol 10: 30-46. https://doi.org/10.5380/abclima.v10i1.30585

Grace JB (2006) Structural equation modeling and natural systems. Cambridge, Cambridge University Press. https://doi.org/10.1017/CBO9780511617799

Hooper D, Coughlan J, Mullen M (2008) Structural equation modelling: guidelines for determining model fit. Electron J Bus Res Methods 6:53-60

Keuskamp JA, Dingemans BJJ, Lehtinen T, Sarneel JM, Hefting MM (2013) Tea bag index: a novel approach to collect uniform decomposition data across ecosystems. Methods Ecol Evol 4:1070-1075. https://doi.org/10.1111/2041-21 0X.12097 
Krishna MP, Mohan M (2017) Litter decomposition in forest ecosystems: a review. Energ Ecol Environ 2:236-249. https://doi.org/10.1007/s40974-017-0064-9

Lajtha K, Bowden RD, Crow S, Fekete I, Kotroczó Z, Plante A, Simpson MJ, Nadelhoffer KJ (2018) The detrital input and removal treatment (DIRT) network: insights into soil carbon stabilization. Sci Total Environ 640-641: 1112-1120. https://doi.org/10.1016/j.scitotenv.2018.05.388

Legendre P, Legendre L (2012) Numerical ecology, 3rd edn. Elsevier, Amsterdam Lukumbuzya TK, Fyles JW, Côté B (1994) Effects of base-cation fertilization on litter decomposition in a sugar maple forest in southern Quebec. Can J For Res 24:447-452. https://doi.org/10.1139/x94-061

Manzoni S, Piñeiro G, Jackson RB, Jobbágy EG, Kim JH, Porporato A (2012) Analytical models of soil and litter decomposition: solutions for mass loss and time-dependent decay rates. Soil Biol Biochem 50:66-76. https://doi. org/10.1016/j.soilbio.2012.02.029

Mayer M, Matthews B, Rosinger C, Sandén H, Godbold DL, Katzensteiner K (2017) Tree regeneration retards decomposition in a temperate mountain soil after forest gap disturbance. Soil Biol Biochem 115:490-498. https://doi.org/10.101 6/j.soilbio.2017.09.010

Metzger JC, Wutzler T, Valle ND, Filipzik J, Grauer C, Lehmann R, Roggenbuck M, Schelhorn D, Weckmüller J, Küsel K, Totsche KU, Trumbore S, Hildebrandt A (2017) Vegetation impacts soil water content patterns by shaping canopy water fluxes and soil properties. Hydrol Process 31:3783-3795. https:/doi.org/10.1002/hyp.11274

Muñoz Mazón M, Klanderud K, Finegan B, Veintimilla D, Bermeo D, Murrieta E, Delgado D, Sheil D (2020) How forest structure varies with elevation in old growth and secondary forest in Costa Rica. Forest Ecol Manag 469:118191. https://doi.org/10.1016/j.foreco.2020.118191

Naiman RJ, Décamps H, McClain ME (2005) Riparia: ecology, conservation, and management of streamside communities. Elsevier Academic Press, London

Nunes FP, Pinto MTC (2007) Produção de serapilheira em mata ciliar nativa e reflorestada no alto São Francisco, Minas Gerais. Biota Neotrop 7:97-102. https://doi.org/10.1590/\$1676-06032007000300011

Oliveira RAC, Marques R, Marques MCM (2019) Plant diversity and local environmental conditions indirectly affect litter decomposition in a tropical forest. Appl Soil Ecol 134:45-53. https://doi.org/10.1016/j.apsoil.2018.09.016

Osman KT (2013) Nutrient dynamics in forest soil. In: Osman KT (ed) Forest soils: properties and management. Springer, Cham, pp 97-121

Ottermanns R, Hopp PW, Guschal M, dos Santos GP, Meyer S, Roß-Nickoll M (2011) Causal relationship between leaf litter beetle communities and regeneration patterns of vegetation in the Atlantic rainforest of Southern Brazil (Mata Atlântica). Ecol Complex 8:299-309. https://doi.org/10.1016/j.ecocom.2011.06.001

Parron LM, Bustamante MMC, Markewitz D (2011) Fluxes of nitrogen and phosphorus in a gallery forest in the Cerrado of Central Brazil. Biogeochemistry 105:89-104. https://doi.org/10.1007/s10533-010-9537-z

Pausas JG, Bond WJ (2020) On the three major recycling pathways in terrestrial ecosystems. Trends Ecol Evol 35(9):767-775. https://doi.org/10.1016/j.tree.2020.04.004

Petraglia A, Cacciatori C, Chelli S, Fenu G, Calderisi G, Gargano D, Abeli T, Orsenigo S, Carbognani M (2019) Litter decomposition: effects of temperature driven by soil moisture and vegetation type. Plant and Soil 435: 187-200. https://doi.org/10.1007/s11104-018-3889-x

R Core Team (2018) R: a language and environment for statistical computing. R Found. Stat. Comput, Vienn https://www.R-project.org/. Accessed 15 May 2020

Rodrigues PMS, Schaefer CEGR, de Oliveira SJ, Júnior WGF, dos Santos RM, Neri AV (2018) The influence of soil on vegetation structure and plant diversity in different tropical savannic and forest habitats. J Plant Ecol 11:226-236. https:/doi.org/10.1093/jpe/ rtw135

Rosseel Y (2012) Lavaan: an R package for structural equation modeling. J Stat Softw 48:1-36

Rossi M (2017) Mapa pedológico do Estado de São Paulo: revisado e ampliado. Instituto Florestal, São Paulo

Rot BW, Naiman RJ, Bilby RE (2000) Stream channel configuration, landform, and riparian forest structure in the Cascade Mountains, Washington. Can J Fish Aquat Sci 57:699-707. https://doi.org/10.1139/f00-002

Saint-Laurent D, Arsenault-Boucher L (2020) Soil properties and rate of organic matter decomposition in riparian woodlands using the TBI protocol. Geoderma 358:113976. https://doi.org/10.1016/j.geoderma.2019.113976

Sayer EJ, Banin LF (2016) Tree nutrient status and nutrient cycling in tropical forest-lessons from fertilization experiments. In: Goldstein G, Santiago LS (eds) Tropical tree physiology. Springer International Publishing Switzerland AG, Cham, pp 275-297

Sayer EJ, Rodtassana C, Sheldrake M, Bréchet LM, Ashford OS, Lopez-Sangil L, Kerdraon-Byrne D, Castro B, Turner BL, Wright SJ, Tanner EVJ (2020) Revisiting nutrient cycling by litterfall-insights from 15 years of litter manipulation in old-growth lowland tropical forest. Adv Ecol Res 62:173-223. https://doi. org/10.1016/bs.aecr.2020.01.002

Schoenholtz SH, Miegroet HV, Burger JA (2000) A review of chemical and physical properties as indicators of forest soil quality: challenges and opportunities. Forest Ecol Manag 138:335-356. https://doi.org/10.1016/S03 78-1127(00)00423-0

Setälä H, Marshall VG, Trofymow JA (1996) Influence of body size of soil fauna on litter decomposition and ${ }^{15} \mathrm{~N}$ uptake by poplar in a pot trial. Soil Biol Biochem 28:1661-1675. https://doi.org/10.1016/S0038-0717(96)00252-0

Silva-Sánchez A, Soares M, Rousk J (2019) Testing the dependence of microbial growth and carbon use efficiency on nitrogen availability, $\mathrm{pH}$, and organic matter quality. Soil Biol Biochem 134:25-35. https://doi.org/10.1016/j.soilbio.2 019.03.008

Soares JAH, de Souza ALT, de Abreu Pestana LF, Tanaka MO (2020) Combined effects of soil fertility and vegetation structure on early decomposition of organic matter in a tropical riparian zone. Ecol Eng 152:105899. https://doi. org/10.1016/j.ecoleng.2020.105899

Souza RG, Camargo MBP, Lania DG, Moraes JFL (2007) Classificação climática de Köppen e de Thornthwaite e sua aplicabilidade na determinação de zonas agroclimáticas para o estado de são Paulo. Bragantia 66:711-720. https://doi. org/10.1590/S0006-87052007000400022

Souza ALT, Fonseca DG, Liborio RA, Tanaka MO (2013) Influence of riparian vegetation and forest structure on the water quality of rural low-order streams in SE Brazil. Forest Ecol Manag 298:12-18. https://doi.org/10.1016/j. foreco.2013.02.022

Spielvogel S, Prietzel J, Kögel-Knabner I (2016) Stand scale variability of topsoil organic matter composition in a high-elevation Norway spruce forest ecosystem. Geoderma 267:112-122. https://doi.org/10.1016/j.geoderma.201 5.12 .001

Teixeira HM, Cardoso IM, Bianchi FJJA, Silva AC, Jamme D, Peña-Claros M (2020) Linking vegetation and soil functions during secondary forest succession in the Atlantic forest. Forest Ecol Manag 457:117696

van Raij B, de Andrade JC, Cantarella H, Quaggio JA (2001) Análise química para avaliação da fertilidade de solos tropicais. Instituto Agronômico, Campinas

Wekesa C, Kirui BK, Maranga EK, Muturi GM (2019) Variations in forest structure, tree species diversity and above-ground biomass in edges to interior cores of fragmented forest patches of Taita Hills, Kenya. Forest Ecol Manag 440:4860. https://doi.org/10.1016/j.foreco.2019.03.011

Wider RK, Lang GE (1982) A critique of the analytical methods used in examining decomposition data obtained from litter bags. Ecology 63:1636-1642

Wiesmeier M, Urbanski L, Hobley E, Lang B, von Lützow M, Marin-Spiotta E, van Wesemael B, Rabot E, Ließ M, Garcia-Franco N, Wollschläger U, Vogel H-J, Kögel-Knabner I (2019) Soil organic carbon storage as a key function of soils - a review of drivers and indicators at various scales. Geoderma 333:149-162. https://doi.org/10.1016/j.geoderma.2018.07.026

Woodward KB, Fellows CS, Mitrovic SM, Sheldon F (2015) Patterns and bioavailability of soil nutrients and carbon across a gradient of inundation frequencies in a lowland river channel, Murray-Darling basin, Australia. Agric Ecosyst Environ 205:1-8. https://doi.org/10.1016/j.agee.2015.02.019

Yeong KL, Reynolds G, Hill JK (2016) Leaf litter decomposition rates in degraded and fragmented tropical rain forests of Borneo. Biotropica 48:443-452. https://doi.org/10.1111/btp.12319

Zhou Z, Wang C, Luo Y (2018) Effects of forest degradation on microbial communities and soil carbon cycling: a global meta-analysis. Glob Ecol Biogeogr 27:110-124. https://doi.org/10.1111/geb.12663 